Terbit online pada laman web jurnal: http://jurnal.iaii.or.id

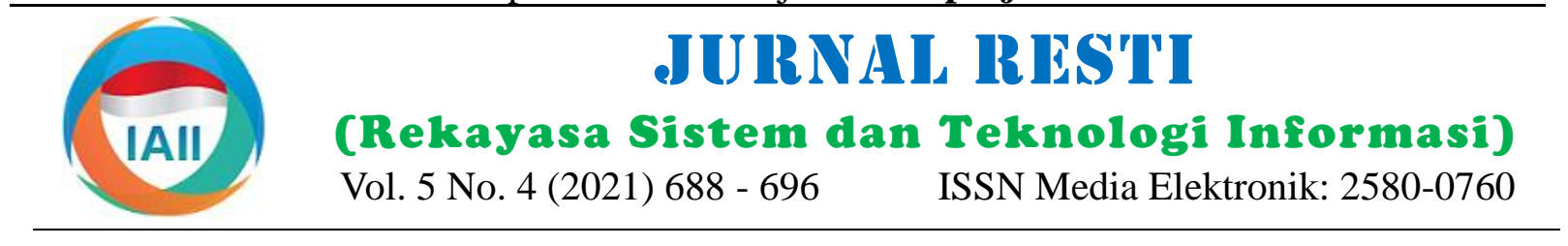

\title{
Klasifikasi Citra Burung Lovebird Menggunakan Decision Tree dengan Empat Jenis Evaluasi
}

\author{
Aviv Yuniar Rahman \\ Program Studi Teknik Informatika, Fakultas Teknik, Universitas Widyagama Malang \\ aviv@widyagama.ac.id
}

\begin{abstract}
Lovebird is a pet that many people in Indonesia have known. The diversity of species, coat color, and body shape gives it its charm. As well in this lovebird bird has its uniqueness of various rare colors. However, many ordinary people have difficulty distinguishing the types of lovebirds. This research is needed to improve previous study performance in classifying lovebird images using the Decision Tree J48 algorithm with 4 types of evaluation. In this case, also to reduce the stage of feature extraction to speed up the computational process. Based on available comparisons, the results obtained at the same split ratio with a comparison of 60:40 in Decision Tree J48 have the precision of 1,000, recall of 1,000, $f$-measure of 1,000, and accuracy value of $100 \%$. Then the Artificial Neural Network with a split ratio of 60:40 has a precision of 0.854 , recall of $0.843, f$ measurement of 0.841 , and an accuracy value of $84.25 \%$. These results prove that by testing the first-level extraction on color features, Decision Tree J48 is superior in classifying images of lovebird species, and Decision Tree J48 can improve performance and produce the best accuracy.
\end{abstract}

Keywords: Lovebird, ANN, Decision Tree, Precision, Recall, F-measure.

\begin{abstract}
Abstrak
Burung lovebird merupakan hewan peliharaan yang telah dikenal oleh banyak masyarakat di Indonesia. Keanekaragam jenis, warna bulu, serta bentuk tubuhnya memberikan daya tarik tersendiri bagi pecinta. Serta dalam burung lovebird ini juga memiliki keunikan sendiri yang beragam warna-warna langka. Namun, banyak diantara masyarakat awam kesulitan dalam membedakan jenis burung lovebird. Dari segi jenis, masyarakat cenderung melihat sesuai dengan yang ada di pada umumnya. Semakin jenis burung berbeda dan jarang diketahui masyarakat, maka akan memiliki nilai jual yang tinggi pada burung lovebird. Penelitian ini diperlukan untuk memperbaiki kinerja dari penelitian sebelumnya dalam proses klasifikasi citra burung lovebird menggunakan algoritma Decision Tree J48 dengan 4 jenis evaluasi. Serta dalam hal ini juga untuk mengurangi tahapan fitur ekstraksi agar mempercepat pada proses komputasi. Berdasarkan perbandingan yang sudah diketahui, Hasil yang didapatkan pada split ratio yang sama dengan perbandingan 60:40 pada Decision Tree J48 memiliki hasil precision 1.000, recall 1.000, f-measure 1.000 dan nilai accuracy mencapai 100\%. Kemudian pada Artificial Neural Network dengan split ratio 60:40 memiliki hasil precision 0.854 , recall 0.843 , f-measure 0.841 dan nilai accuracy mencapai $84.25 \%$. Hasil ini membuktikan dengan pengujian ekstraksi tingkat pertama pada fitur warna Decision Tree J48 lebih unggul dalam mengklasifikasi citra jenis burung lovebird, serta Decision Tree J48 mampu memperbaiki kinerja dan menghasilkan accuracy yang terbaik.
\end{abstract}

Kata kunci: Lovebird, ANN, Decision Tree, Precision, Recall, F-measure.

\section{Pendahuluan}

Burung lovebird merupakan hewan peliharaan yang telah dikenal oleh banyak masyarakat [1] di Indonesia. Keanekaragam jenis, warna bulu [2], serta bentuk tubuhnya yang mungil [3] memberikan daya tarik tersendiri bagi pecinta [4] burung tersebut. Burung ini akan memberikan kicauan balasan ketika mendengarkan suara yang tinggi di sekitarnya. Burung lovebird di
Indonesia sendiri telah menjadi trending masyarakat, karena burung lovebird ini sering dijadikan kontes untuk dalam menghasilkan suara unik. Serta dalam burung lovebird ini juga memiliki keunikan sendiri yang beragam warna langka [5]. Namun, banyak diantara masyarakat awam kesulitan dalam membedakan jenis membedakan jenis burung lovebird. Dari segi jenis, masyarakat cenderung melihat sesuai dengan yang ada di pada umumnya. Semakin jenis burung berbeda dan

Diterima Redaksi: 11-06-2021 | Selesai Revisi: 02-08-2021 | Diterbitkan Online: 20-08-2021 
jarang diketahui masyarakat, maka akan memiliki nilai dengan cara memisahkan citra lemak dan daging jual yang tinggi pada burung lovebird. Hal ini juga akan menggunakan Decision Tree J48. Data yang digunakan membuat daya tarik tersendiri kepada para pecinta dalam proses klasifikasi yaitu berupa 12 kelas data burung lovebird. Bukan hanya itu, masyarakat kini juga daging sapi. Hasil dalam klasifikasi daging sapi pada menjadikan burung lovebird untuk kontes kicauan algoritma Decision Tree J48 memiliki tingkat akurasi burung lovebird. mencapai 90\%. [16].

Dalam paparan singkat burung lovebird telah Selanjutnya keunggulan dalam Decision Tree J48 yang menjadikan penelitian telah dilakukan oleh [6] yaitu ketiga digunakan untuk deteksi diagnosis otak. Metode menguji klasifikasi citra jenis burung lovebird yang digunakan untuk mendeteksi tumor otak menggunakan Local Binary Pattern (LBP) [7][8] dan menggunakan 3 jenis tumor yaitu meningioma, glioma, fuzzy logic [9][10]. Dalam penelitian ini objek gambar hipofisis. Proses utama yang digunakan yaitu fitur yang diuji hanya pada bentuk kepala dan warna. ekstraksi histogram gradien yang berorientasi pada citra Evaluasi yang digunakan hanya menggunakan nilai gambar yang di deteksi. Hasil yang didapatkan dalam accuracy dan memperoleh hasil accuracy kurang dari diagnosis deteksi tumor menggunakan Decision Tree 92\%. Namun pengujian ini hanya menggunakan kepala $J 48$ yaitu dapat mengklasifikasikan gambar dengan nilai dan warna saja sebagai penelitian, yang artinya tidak akurasi mencapai 96,4\%[17]. menggunakan keseluruhan badan dalam proses klasifikasi burung lovebird. Dalam hal ini nantinya juga akan mempengaruhi proses klasifikasi dari jenis burung lovebird.

Algoritma Decision Tree J48 dapat diterapkan pada klasifikasi gambar gigitan ular, kualitas daging sapi dan deteksi diagnosis otak. Hasil yang didapatkan dalam Decision Tree J48 mampu meningkatkan kinerja dengan Selanjutnya penelitian klasifikasi citra jenis burung tingkat akurasi diatas $90 \%$. Oleh karena itu, Decision lovebird oleh [11] menguji klasifikasi citra jenis burung Tree J48 dapat diusulkan pada penelitian klasifikasi citra lovebird menggunakan Artificial Neural Network [10] burung lovebird.

dan fuzzy logic [12]. Dalam penelitian ini, proses evaluasi dengan menggunakan 3 tingkat fitur, yaitu fitur tekstur, bentuk dan warna dengan parameter accuracy. Perbandingan tingkat accuracy yang diperoleh menggunakan Artificial Neural Network [13][14] sebesar $88.88 \%$ untuk split ratio 60:40. Dalam hal ini pada saat proses pengujian citra gambar dari burung lovebird dilakukan pengambilan secara keseluruhan pixel dari gambar. Oleh karena itu, penelitian tersebut memerlukan waktu yang cukup lama pada proses komputasi dalam mendapatkan hasil dari 1 jenis burung lovebird.

Berdasarkan uraian singkat yang dijelaskan, penelitian ini diperlukan untuk memperbaiki kinerja dari penelitian sebelumnya dengan proses klasifikasi citra burung lovebird menggunakan algoritma Decision Tree J48. Proses klasifikasi juga menggunakan 4 jenis evaluasi yaitu precision, recall, f-measure, dan accuracy. Tujuan lain juga untuk mengurangi tahapan fitur ekstraksi agar mempercepat proses komputasi dalam tiga fitur komputasi

\section{Metode Penelitian}

Pada metode penelitian ini, merupakan proses dalam Untuk meningkatkan kinerja klasifikasi citra burung klasifikasi citra burung lovebird. Diawali dengan prelovebird pada penelitian kedua. Dari hasil literatur processing dengan 3 tahap yaitu data training, data review klasifikasi citra menggunakan Decision tree J48 testing dan fitur ekstraksi. Kemudian tahap kedua yaitu dapat terlihat nilai akurasinya di atas $90 \%$. Pertama, proses perbandingan antara Artificial Neural Network algoritma Decision tree J48 ini dapat diterapkan untuk dengan Decision Tree j48. Tahap terakhir yaitu proses proses klasifikasi gambar gigitan ular. Metode yang evaluasi menggunakan accuracy, precision, recall, dan digunakan dalam yaitu berupa gambar luka gigitan ular $f$-measure yang ditujukan Pada Gambar 1 .

yang terdiri dari 34 gambar gigitan ular dengan 16 gambar ular berbisa dan 18 tidak berbisa. Kemudian fitur yang dipakai yaitu centroid, area, dan eccentricity. Hasil dari evaluasi didapatkan bahwa parameter jumlah centroid dan jarak memiliki pengaruh paling signifikan dalam membantu klasifikasi gambar luka gigitan ular dengan akurasi $97.14 \%$, precision $92.85 \%$, recall 91.42\%, dan F1 score 92.06\% [15].

Kemudian keunggulan Decision Tree J48 yang kedua yaitu digunakan untuk mengetahui kualitas dalam daging sapi berbasis android. Proses klasifikasi bertujuan untuk mengidentifikasi tingkat kesegaran

\subsection{Data Training dan Testing}

Dalam hal ini, data training dan testing digunakan untuk pengambilan data citra burung lovebird agar hasil citra yang akan di uji dapat melakukan proses ekstraksi dengan lebih baik dan terarah. Kemudian pada pengumpulan data, dibutuhkan kamera DSLR dengan tipe Canon Eos 4000D untuk proses pengambilan foto maupun gambar dari 9 jenis burung lovebird. Proses pengambilan citra sembilan jenis burung lovebird diantaranya lovebird Albino, batman, biola, blorok, dakocan, lutino, olive, parblue, dan violet. Kemudian proses pengambilan gambar berada pada peternakan

DOI: https://doi.org/10.29207/resti.v5i4.3210

Creative Commons Attribution 4.0 International License (CC BY 4.0) 


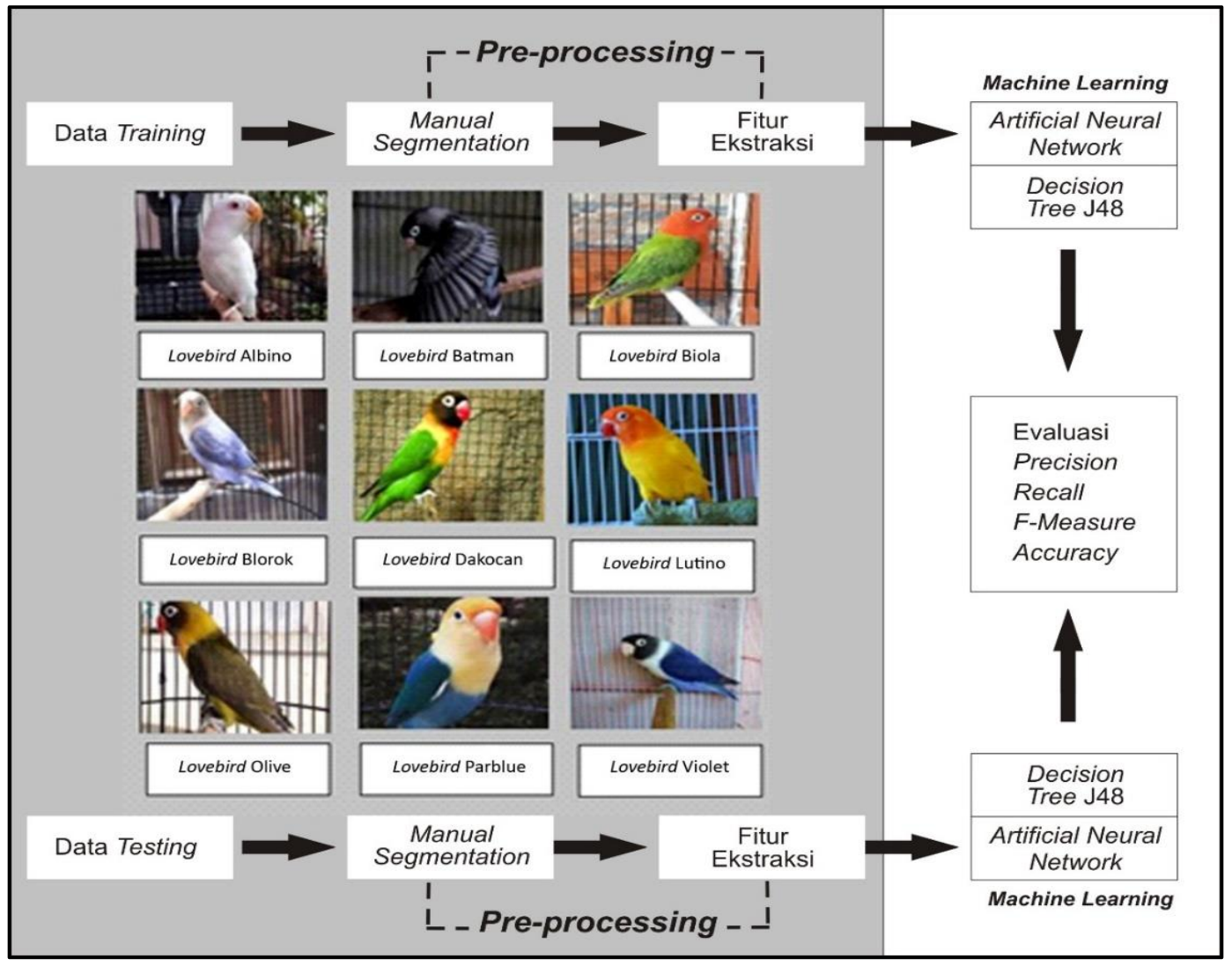

Gambar 1. Sistem Evaluasi Klasifikasi Citra Burung Lovebird

burung lovebird di kecamatan Pakis Kota Malang. Pada 90 untuk mendapatkan hasil yang maksimal. proses klasifikasi citra jenis burung lovebird ini Selanjutnya yaitu fitur warna, dimana dalam hal ini menggunakan 540 data uji. Serta dalam perbandingan mengidentifikasi citra burung lovebird sesuai dengan training dan testing menggunakan split ratio. Metode jenis warna dari burung lovebird. Ketiga fitur ini dalam split ratio ini merupakan perbandingan antara diperlukan untuk mendapatkan hasil perbandingan dari $10 \%$ data training dibandingkan $90 \%$ data testing, serta masing-masing metode, baik Artificial Neural Network $90 \%$ data training dibandingkan $10 \%$ data testing.

\subsection{Manual Segmentation} maupun dengan Decision Tree J48. Pengujian akan dilakukan dengan menguji tiga tingkatan fitur yang digabungkan dari ketiga ekstraksi fitur.

Pada manual segmentation ini merupakan proses menghilangkan background gambar ataupun latar

\subsubsection{Fitur Tekstur}

belakang dari gambar yang telah di ambil untuk bahan Pada fitur tekstur ini merupakan proses identifikasi dari evaluasi. Pada gambar ini nantinya akan diubah latar jenis burung lovebird. Dimana nantinya akan belakangnya menjadikan transparence background mengambil dari ciri tekstur burung lovebird. Serta dalam yang dilakukan oleh peneliti secara manual. Serta dalam mendapatkan informasi dan susunan struktur permukaan proses menghilangkan latar belakang ini bertujuan untuk dari citra burung lovebird diperlukan nilai keabuan dari membuat lebih akurat dalam pengujian klasifikasi citra gambar digunakan Gray Level Co-occurrence Matrix burung lovebird.

\subsection{Fitur Ekstraksi}

(GLCM). Terdapat beberapa tahapan yang dilakukan dalam pengambilan fitur tekstur. Citra warna dirubah menjadi citra grayscale selanjutnya masing - masing

Proses fitur ekstraksi merupakan pengambilan ciri dari nilai dari RGB citra dirubah menjadi abu - abu dengan masing-masing fitur yang ada pada citra burung menggunakan rumus 1 .

lovebird. Fitur tersebut antara lain fitur tekstur yang cara Keabuan $=0.2989^{*} \mathrm{R}+0.5870^{*} \mathrm{G}+0.1140^{*} \mathrm{~B}$ klasifikasinya mengidentifikasi tekstur dari burung lovebird. Kemudian fitur bentuk, dimana dalam fitur Dimana pada rumus 1 parameter $\mathrm{R}$ melambangkan bentuk ini mengidentifikasi pola dari burung lovebird warna merah, G warna hijau, dan B warna biru. yang sesuai dengan bentuk burung lovebird dengan Kemudian rumus 2 untuk mengukur kekuatan perbedaan berbagai jenis rotasi atau sudut pandang pada $10^{\circ}$ sampai

DOI: https://doi.org/10.29207/resti.v5i4.3210

Creative Commons Attribution 4.0 International License (CC BY 4.0) 
Aviv Yuniar Rahman

Jurnal RESTI (Rekayasa Sistem dan Teknologi Informasi) Vol. 5 No. 4 (2021) 688 - 696

Tabel 1. Perbandingan evaluasi ekstraksi fitur tekstur menggunakan Artificial Neural Network dan Decision Tree J48

\begin{tabular}{|c|c|c|c|c|c|c|c|c|c|}
\hline \multirow{2}{*}{ Fitur } & \multirow{2}{*}{$\begin{array}{l}\text { split } \\
\text { ratio }\end{array}$} & \multicolumn{4}{|c|}{ Artificial Neural Network } & \multicolumn{4}{|c|}{ Decision Tree J48 } \\
\hline & & $\mathrm{P}$ & $\mathrm{R}$ & $\mathrm{F}$ & A & $\mathrm{P}$ & $\mathrm{R}$ & $\mathrm{F}$ & A \\
\hline \multirow{6}{*}{ Tekstur } & $10: 90$ & 0.400 & 0.337 & 0.308 & $33.70 \%$ & 0.271 & 0.272 & 0.258 & $27.16 \%$ \\
\hline & $30: 70$ & 0.497 & 0.447 & 0.435 & $44.70 \%$ & 0.426 & 0.397 & 0.393 & $39.68 \%$ \\
\hline & $40: 60$ & 0.423 & 0.389 & 0.387 & $38.80 \%$ & 0.448 & 0.432 & 0.430 & $43.20 \%$ \\
\hline & $70: 30$ & 0.578 & 0.512 & 0.502 & $51.20 \%$ & 0.534 & 0.525 & 0.524 & $52.46 \%$ \\
\hline & $80: 20$ & 0.438 & 0.417 & 0.402 & $41.60 \%$ & 0.603 & 0.574 & 0.578 & $57.40 \%$ \\
\hline & $90: 10$ & 0.536 & 0.463 & 0.481 & $46.20 \%$ & 0.604 & 0.611 & 0.598 & $61.11 \%$ \\
\hline
\end{tabular}

intensitas dalam citra, korelasi rumus 3 untuk mengukur 2.3.3 Fitur Warna

keterkaitan linear pada derajat citra grayscale, energy.

Kemudian dalam fitur warna ini merupakan proses Sedangkan pada rumus 4 untuk mengukur konsentrasi identifikasi burung lovebird berdasarkan sesuai dengan pasangan intensitas matriks co-occurrence. Dalam warna dari masing-masing burung lovebird. Serta dalam homogeniti yang terdapat pada rumus 5 untuk mengukur fitur warna digunakan untuk menguji perbedaan nilai nilai kesamaan variasi dari intensitas citra, dan entropi fitur dari tiap citra gambar burung lovebird yang indah rumus 6 untuk mengukur keteracakan dari distribusi dan bervariasi. Proses pengolahan citra berdasarkan fitur intensitas.

$\sum_{k} k^{2}\left[\Sigma_{i} \Sigma_{j} p(i, j)\right]$

$\sum_{i, j} \frac{\left(i-\mu_{i}\right)\left(j-\mu_{j}\right) p(i, j)}{\sigma_{i} \sigma_{j}}$

$\sum_{i, j} p(i, j)^{2}$

$\sum_{i, j} \frac{p(i, j)}{1+|i-j|}$

$-\sum_{i, j} P(i, j) \log P(i, j)$

Pada rumus 2 sampai rumus 6 parameter $p$ merupakan nilai kemungkinan yang bernilai nol hingga satu. Lambang $\sigma$ merupakan komponen dalam matriks cooccurence. Pada lambang $i$ dan $j$ menandakan bagian dari intensitas yang berdekatan, dengan masing-masing nomor baris dan nomor kolom merupakan gambaran dalam matriks.

\subsubsection{Fitur Bentuk}

Pada fitur bentuk ini merupakan proses pengambilan ciri bentuk dari burung lovebird, dimana dalam bentuk dari burung lovebird nantinya akan memiliki nilai ciri yang berbeda. Fitur bentuk juga berguna untuk membedakan perbandingan jarak objek citra burung lovebird antara satu dengan yang lain. Nilai ciri yang diekstraksi pada fitur ini yaitu metric dan eccentricity. Variabel pada rumus 7 adalah e untuk eccentricity, a melambangkan foci ellips mayor, dan b melambangkan foci ellips minor. Variabel pada rumus 8 adalah $\mathrm{M}$ untuk metric, A adalah area, dan $\mathrm{C}$ adalah lingkar piksel yang memiliki ukuran intensitas warna.

$$
\begin{aligned}
& e=\sqrt{1-\frac{b^{2}}{a^{2}}} \\
& M=\frac{4 \pi \times A}{c^{2}}
\end{aligned}
$$
warna ini, dilakukan sesuai dengan warna keseluruhan dari burung lovebird, mulai dari warna kepala sampai dengan kaki.

(3) Tahap awal yang dilakukan dalam mengekstraksi fitur warna yaitu mengubah warna RGB menjadi grayscale.

(4) Penyusun gambar yang terdapat pada rentang nilai piksel warna keabuan di kelompokan menjadi 8 dari

(5) masing-masing piksel. Banyak piksel warna yang menyusun gambar dinormalisasi pada tiap kelompok

(6) jumlah anggota. Susunan dari gambar adalah piksel piksel yang memiliki ukuran intensitas warna.

\subsection{Artificial Neural Network}

Artificial Neural Network (ANN) digunakan pada penelitian sebelumnya untuk klasifikasi citra burung lovebird. Perbandingan nilai precision, recall, $f$ measure, dan accuracy terbaik diukur dengan mengatur nilai learning rate dari 0.1 sampai 0.9. Pada lapisan yang berada pada Artificial Neural Network terdiri dari Input layer untuk fitur, hidden layer untuk kelas, dan output layer. Untuk menghitung kalkulasi kombinasi linear digunakan rumus 9.

$n e t_{j}^{(h)}=\sum_{i=1}^{I} w_{i j}^{(h)} x_{i}^{(h-1)}+b_{j}^{(h)}$

Dimana pada rumus $9 x_{i}^{(h-1)}$ merupakan input pada neuron ke- $i$ pada layer ke- $h-1$. Lambang $\mathrm{w}_{\mathrm{ij}}{ }^{(\mathrm{h})}$ merupakan weight yang menghubungkan neuron ke- $i$ pada layer ke- $h-1$ dengan neuron ke-j pada layer ke- $h$. Untuk $b_{j}{ }^{(\mathrm{h})}$ melambangkan output pada neuron ke-j pada layer ke- $h$.

\subsection{Decision Tree J48}

(7) Decision Tree J48 digunakan untuk klasifikasi citra burung lovebird yang telah diusulkan pada penelitian (8) ini. Input dari fitur ekstraksi ini terdiri dari 3 tingkat fitur

DOI: https://doi.org/10.29207/resti.v5i4.3210

Creative Commons Attribution 4.0 International License (CC BY 4.0) 
Aviv Yuniar Rahman

Jurnal RESTI (Rekayasa Sistem dan Teknologi Informasi) Vol. 5 No. 4 (2021) 688 - 696

Tabel 2. Perbandingan evaluasi ekstraksi fitur bentuk menggunakan Artificial Neural Network dan Decision Tree J48

\begin{tabular}{|c|c|c|c|c|c|c|c|c|c|}
\hline \multirow{2}{*}{ Fitur } & \multirow{2}{*}{$\begin{array}{l}\text { split } \\
\text { ratio }\end{array}$} & \multicolumn{4}{|c|}{ Artificial Neural Network } & \multicolumn{4}{|c|}{ Decision Tree J48 } \\
\hline & & $\mathrm{P}$ & $\mathrm{R}$ & $\mathrm{F}$ & $\mathrm{A}$ & $\mathrm{P}$ & $\mathrm{R}$ & F & $\mathrm{A}$ \\
\hline \multirow{6}{*}{ Bentuk } & $10: 90$ & 0.585 & 0.508 & 0.477 & $50.82 \%$ & 0.619 & 0.597 & 0.578 & $59.67 \%$ \\
\hline & $30: 70$ & 0.591 & 0.532 & 0.506 & $53.17 \%$ & 0.876 & 0.870 & 0.869 & $87.03 \%$ \\
\hline & $40: 60$ & 0.000 & 0.549 & 0.000 & $54.93 \%$ & 0.902 & 0.898 & 0.899 & $89.81 \%$ \\
\hline & $70: 30$ & 0.764 & 0.691 & 0.693 & $69.13 \%$ & 0.962 & 0.957 & 0.957 & $95.67 \%$ \\
\hline & $80: 20$ & 0.714 & 0.657 & 0.643 & $65.74 \%$ & 0.991 & 0.991 & 0.991 & $99.07 \%$ \\
\hline & $90: 10$ & 0.000 & 0.630 & 0.000 & $62.96 \%$ & 0.985 & 0.981 & 0.982 & $98.14 \%$ \\
\hline
\end{tabular}

yaitu, fitur tekstur yang mengolah citra berdasarkan negatif merupakan jumlah yang diprediksi salah. $F P$ dalam tekstur yang ada pada tubuh burung lovebird. atau false negative Ketika diprediksi ternyata bernilai Pada fitur bentuk ini mengolah citra berdasarkan dengan positif. bentuk dari burung lovebird sesuai dengan jenis yang
ada. Kemudian pada fitur warna, mengolah sebuah citra Precision $=\frac{T P}{T P+F P}$

berdasarkan warna yang ada pada burung lovebird.

Dalam proses pengolahan terdapat nilai gain teratas dari Recall $=\frac{T P}{T P+F N}$

ciri atau karakter yang ada. Pada rumus 10 merupakan perhitungan dari gain.

$\operatorname{Gain}(S, A)=\operatorname{Entropy}(S)-\sum^{n} * \operatorname{Entropy}(S i)$

$F-$ measure $=\frac{\text { Precision } \times \text { Recall }}{\text { Precision }+ \text { Recall }}$

Accuracy $=\frac{T P+T N}{T P+F P+T N+F N}$ Dimana pada rumus $10 \mathrm{~S}$ melambangkan himpunan
kasus. Untuk variabel A melambangkan atribut, dan $\mathrm{n}$ melambangkan jumlah partisi atribut A. Variabel Si 3. Hasil dan Pembahasan

melambangkan jumlah kasus pada partisi ke-i, dan $\mathrm{S}$ melambangkan jumlah kasus dalam $\mathrm{S}$.

Pada proses evaluasi menggunakan parameter accuracy, precision, recall dan f-measure sebagai bahan 2.6. Evaluasi Precision, Recall, F-Measure, dan perbandingan dari Artificial Neural Network dan Accuracy

Pada bagian merupakan proses evaluasi klasifikasi jenis burung lovebird menggunakan 4 jenis evaluasi. Berdasarkan 4 jenis evaluasi, precision diperlukan untuk mengidentifikasi batas sebenarnya dari gambar burung lovebird. Serta keakuratan dalam tingkat presisi pada saat pengujian sangat dibutuhkan untuk menghasilkan nilai yang maksimal dalam klasifikasi jenis burung lovebird. Kemudian pada recall diperlukan untuk mengukur tingkat dari keberhasilan proses dari klasifikasi pada burung lovebird. Serta dalam recall nilai terendah yang telah diuji akan ditemukan kembali untuk diproses ulang dan di uji kembali. Selanjutnya yaitu evaluasi jenis $f$-measure, dimana dalam hal ini merupakan hasil dari rata-rata antara precision dan recall. Dalam hal ini nilai antara precision dan recall di evaluasi sesuai dengan batas masing-masing, kemudian akan di uji pada batas yang sebenarnya yaitu yang ada pada fitur tekstur, fitur bentuk, dan fitur warna.

Decision Tree J48. Berdasarkan pada Tabel 1 merupakan hasil nilai perbandingan pada tingkat 1 pada nilai terendah dalam Artificial Neural Network ada pada split ratio 10:90 dengan nilai precision 0.400 , recall 0.337, f-measure 0.308 dan nilai accuracy mencapai $33.70 \%$. Data yang didapatkan pada split ratio 10:90 merupakan 10 data training dan 90 data testing. Kemudian dalam Decision Tree J48 juga memiliki nilai minimal yang ada pada split ratio 10:90 dengan nilai precision 0.271 , recall 0.272 , $f$-measure 0.258 dan nilai akurasi hanya mencapai $27.16 \%$. Selanjutnya pada Tabel 1 dari Artificial neural network memiliki nilai tertinggi yang ada pada split ratio 70:30 dengan nilai precision 0.578 , recall $0.512, f$-measure 0.502 dan nilai accuracy sebesar $51.20 \%$. Kemudian pada Decision Tree J48 juga memiliki nilai tertinggi pada split ratio 90:10 dengan nilai precision 0.604 , recall $0.611, f$ measure 0.598 dan nilai accuracy sebesar $61.11 \%$. Dalam hal ini Decision tree $J 48$ memiliki nilai yang lebih tinggi 10\% dibandingkan dengan Artificial Neural Proses evaluasi precision, recall, f-measure, dan Network. Hal ini Decision tree J48 mengolah sebuah accuracy ini digunakan untuk mengukur kinerja hasil gambar berdasarkan dengan tekstur dalam gambar sistem. Pada rumus 11 sampai rumus 14 merupakan burung lovebird. Sedangkan dalam Artificial Neural pengukuran yang dilakukan pada confusiion matrix. Network pada proses pengolahan citra burung lovebird Dimana pada rumus 11 TP adalah prediksi positif yang menggunakan seusai dengan keseluruhan gambar yang dijumlahkan semua dan benar positif. $T N$ atau benar ada dan tidak berdasarkan tekstur dalam gambar.

DOI: https://doi.org/10.29207/resti.v5i4.3210

Creative Commons Attribution 4.0 International License (CC BY 4.0) 
Aviv Yuniar Rahman

Jurnal RESTI (Rekayasa Sistem dan Teknologi Informasi) Vol. 5 No. 4 (2021) 688 - 696

Tabel 3 Perbandingan evaluasi ekstraksi fitur warna menggunakan Artificial Neural Network dan Decision Tree J48

\begin{tabular}{|c|c|c|c|c|c|c|c|c|c|}
\hline \multirow{2}{*}{ Fitur } & \multirow{2}{*}{$\begin{array}{l}\text { split } \\
\text { ratio }\end{array}$} & \multicolumn{4}{|c|}{ Artificial Neural Network } & \multicolumn{4}{|c|}{ Decision Tree J48 } \\
\hline & & $\mathrm{P}$ & $\mathrm{R}$ & $\mathrm{F}$ & $\mathrm{A}$ & $\mathrm{P}$ & $\mathrm{R}$ & $\mathrm{F}$ & A \\
\hline \multirow{7}{*}{ Warna } & $10: 90$ & 0.600 & 0.584 & 0.575 & $58.43 \%$ & 0.864 & 0.844 & 0.841 & $84.36 \%$ \\
\hline & $30: 70$ & 0.802 & 0.765 & 0.769 & $76.45 \%$ & 1.000 & 1.000 & 1.000 & $100 \%$ \\
\hline & 40:60 & 0.784 & 0.769 & 0.769 & $76.85 \%$ & 1.000 & 1.000 & 1.000 & $100 \%$ \\
\hline & $50: 50$ & 0.879 & 0.848 & 0.844 & $84.81 \%$ & 1.000 & 1.000 & 1.000 & $100 \%$ \\
\hline & $70: 30$ & 0.818 & 0.772 & 0.773 & $77.16 \%$ & 1.000 & 1.000 & 1.000 & $100 \%$ \\
\hline & $80: 20$ & 0.856 & 0.796 & 0.795 & $79.62 \%$ & 1.000 & 1.000 & 1.000 & $100 \%$ \\
\hline & $90: 10$ & 0.887 & 0.833 & 0.830 & $83.33 \%$ & 1.000 & 1.000 & 1.000 & $100 \%$ \\
\hline
\end{tabular}

Tabel 4 Perbandingan evaluasi ekstraksi fitur tekstur dan bentuk menggunakan Artificial Neural Network dan Decision Tree J48

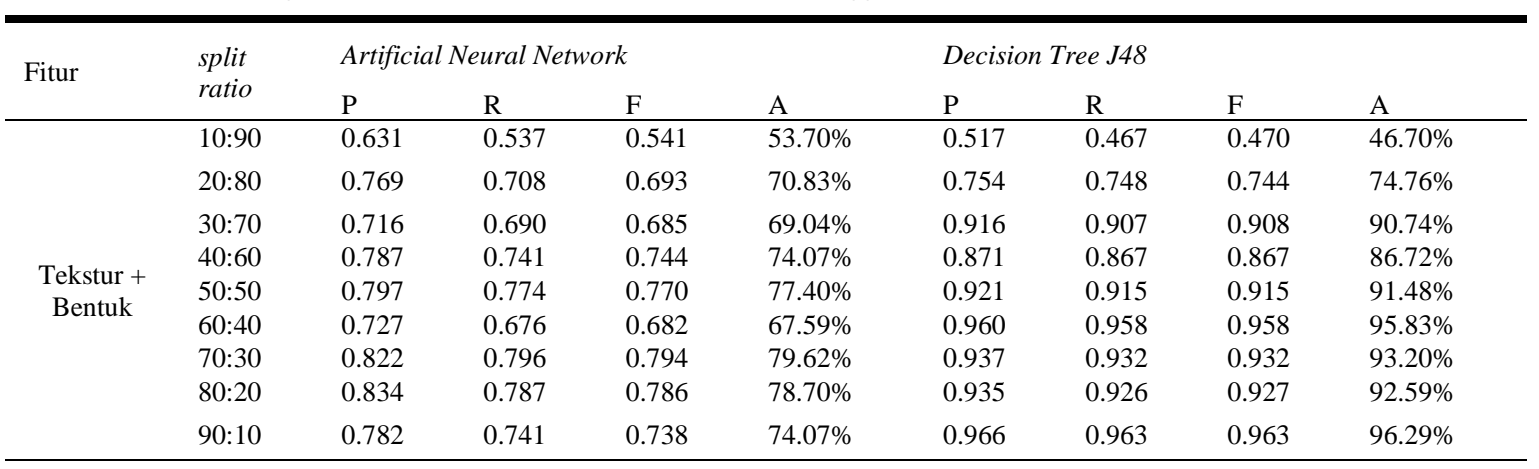

Pada Tabel 2 merupakan hasil dari tingkat 1 fitur bentuk pengujian Decision Tree J48 mengolah sebuah gambar antara Artificial Neural Network dengan Decision Tree citra berdasarkan dari bentuk gambar burung lovebird J48. Pada Tabel 2 diketahui nilai minimal dari Artificial untuk menghasilkan nilai yang maksimal. Sedangkan Neural Network ada pada split ratio 60:40 dengan nilai dalam Artificial Neural Network tidak menutup precision 0.000 , recall $0.481, f$-measure 0.000 dan nilai kemungkinan mengolah data gambar burung lovebird accuracy mencapai $48.14 \%$. Serta pada nilai minimal berdasarkan keseluruhan gambar tanpa memperhatikan Decision Tree J48 ada pada split ratio 10:90 dengan bentuk dari burung lovebird.

nilai precision 0.619 , recall $0.597, f$-measure 0.578 dan nilai accuracy mencapai $59.67 \%$. Selanjutnya pada tingkat 1 fitur bentuk ini juga memiliki nilai maksimal di mulai dari Artificial Neural Network terdapat nilai maksimal pada split ratio 70:30 dengan nilai precision 0.764 , recall $0.691, f$-measure 0.693 dan nilai accuracy mencapai $69.13 \%$. Serta pada Decision Tree J48 ada pada split ratio 80:20 dengan nilai precision 0.991 , recall 0.991 , f-measure 0.991 dan nilai accuracy mencapai $99.07 \%$. Dalam hal ini nilai yang dihasilkan pada Decision Tree J48 jauh lebih tinggi dibandingkan

Selanjutnya pada Tabel 3 merupakan hasil dari tingkat 1 fitur warna antara Artificial Neural Network dengan Decision Tree J48. Dalam hal ini diketahui bahwa nilai minimal dari Artificial Neural Network ada pada split ratio 10:90 dengan nilai precision 0.600 , recall $0.584, f$ measure 0.575 dan nilai accuracy mencapai $58.43 \%$. Selanjutnya pada nilai minimal Decision Tree $\mathbf{J} 48$ ada pada split ratio 10:90 dengan nilai precision 0.864 , recall $0.844, f$-measure 0.841 dan nilai accuracy mencapai $84.36 \%$. dengan Artificial Neural Network. Pada proses

Tabel 5 Perbandingan evaluasi ekstraksi fitur tekstur dan warna menggunakan Artificial Neural Network dan Decision Tree J48

\begin{tabular}{|c|c|c|c|c|c|c|c|c|c|}
\hline Fitur & $\begin{array}{l}\text { split } \\
\text { ratio }\end{array}$ & \multicolumn{4}{|c|}{ Artificial Neural Network } & \multicolumn{4}{|c|}{ Decision Tree J48 } \\
\hline \multirow{6}{*}{$\begin{array}{c}\text { Tekstur + } \\
\text { Warna }\end{array}$} & $10: 90$ & 0.657 & 0.632 & 0.620 & $63.16 \%$ & 0.820 & 0.749 & 0.730 & $74.89 \%$ \\
\hline & $30: 70$ & 0.900 & 0.886 & 0.883 & $88.62 \%$ & 0.979 & 0.976 & 0.976 & $97.61 \%$ \\
\hline & $40: 60$ & 0.858 & 0.849 & 0.846 & $84.87 \%$ & 0.967 & 0.960 & 0.960 & $95.98 \%$ \\
\hline & $70: 30$ & 0.919 & 0.895 & 0.888 & $89.50 \%$ & 0.984 & 0.981 & 0.981 & $98.14 \%$ \\
\hline & $80: 20$ & 0.889 & 0.870 & 0.866 & $87.03 \%$ & 1.000 & 1.000 & 1.000 & $100 \%$ \\
\hline & $90: 10$ & 0.924 & 0.907 & 0.904 & $90.74 \%$ & 1.000 & 1.000 & 1.000 & $100 \%$ \\
\hline
\end{tabular}

DOI: https://doi.org/10.29207/resti.v5i4.3210

Creative Commons Attribution 4.0 International License (CC BY 4.0) 
Aviv Yuniar Rahman

Jurnal RESTI (Rekayasa Sistem dan Teknologi Informasi) Vol. 5 No. 4 (2021) 688 - 696

Tabel 6 Perbandingan evaluasi ekstraksi fitur warna dan bentuk menggunakan Artificial Neural Network dan Decision Tree J48

\begin{tabular}{|c|c|c|c|c|c|c|c|c|c|}
\hline \multirow{2}{*}{ Fitur } & \multirow{2}{*}{$\begin{array}{l}\text { split } \\
\text { ratio }\end{array}$} & \multicolumn{4}{|c|}{ Artificial Neural Network } & \multicolumn{4}{|c|}{ Decision Tree J48 } \\
\hline & & $\mathrm{P}$ & $\mathrm{R}$ & $\mathrm{F}$ & A & $\mathrm{P}$ & $\mathrm{R}$ & $\mathrm{F}$ & A \\
\hline \multirow{6}{*}{$\begin{array}{l}\text { Warna + } \\
\text { Bentuk }\end{array}$} & $10: 90$ & 0.765 & 0.728 & 0.726 & $72.83 \%$ & 0.845 & 0.805 & 0.787 & $80.45 \%$ \\
\hline & $30: 70$ & 0.801 & 0.749 & 0.743 & $74.86 \%$ & 1.000 & 1.000 & 1.000 & $100 \%$ \\
\hline & $40: 60$ & 0.852 & 0.821 & 0.816 & $82.09 \%$ & 0.994 & 0.994 & 0.994 & $99.38 \%$ \\
\hline & $70: 30$ & 0.863 & 0.840 & 0.832 & $83.95 \%$ & 1.000 & 1.000 & 1.000 & $100 \%$ \\
\hline & $80: 20$ & 0.810 & 0.806 & 0.794 & $80.55 \%$ & 1.000 & 1.000 & 1.000 & $100 \%$ \\
\hline & $90: 10$ & 0.902 & 0.852 & 0.852 & $85.18 \%$ & 1.000 & 1.000 & 1.000 & $100 \%$ \\
\hline
\end{tabular}

Pada Tabel 3 ini juga memiliki nilai maksimal yang merupakan hasil dari tingkat ke 2 fitur tekstur dan dimulai dari Artificial Neural Network terdapat nilai bentuk. Dalam hal ini diawali dengan nilai terendah dari maksimal pada split ratio 50:50 dengan nilai precision Artificial Neural Network nilai minimal pada split ratio 0.879 , recall $0.848, f$-measure 0.844 dan nilai accuracy $10: 90$ dengan nilai precision 0.631 , recall $537, f$ mencapai $84.81 \%$. Serta pada Decision Tree $J 48$ ada measure 0.541 dan nilai accuracy $53.70 \%$. Kemudian pada split ratio 30:70 sampai dengan 90:10 yang pada Decision Tree J48 nilai minimal ada pada split menghasilkan nilai precision 1.000 , recall $1.000, f$ - ratio $10: 90$ dengan nilai precision 0.517 , recall $0.467, f$ measure 1.000 dan nilai accuracy mencapai 100\%. measure 0.470 dan accuracy 46.70\%. Dalam Dalam hal ini nilai yang dihasilkan pada Decision Tree perbandingan yang pada Tabel 4 ini juga memiliki nilai J48 terbilang sempurna dibandingkan dengan Artificial maksimal, dari Artificial Neural Network ada pada split Neural Network. Karena pada proses pengujian Decision ratio 70:30 dengan nilai precision 0.822, recall 0.796, $f$ Tree J48 mengolah sebuah gambar citra berdasarkan measure 0.794 dan nilai accuracy $79.62 \%$. Serta pada dari warna pada gambar burung lovebird untuk Decision Tree J48 ada pada split ratio 90:10 dengan menghasilkan nilai yang maksimal. nilai precision 0.966 , recall 0.963 , $f$-measure 0.963 dan nilai accuracy $96.29 \%$. Dalam hal ini nilai dari Decision Kemudian Pada Tabel 4 merupakan hasil perbandingan Tree J48 lebih tinggi dari Artificial Neural Network, antara Artificial Neural Network dengan Decision Tree J48. Serta pada perbandingan yang ada pada Tabel 4 karena dalam proses pengujian dari masing-masing

Tabel 7 Perbandingan evaluasi ekstraksi fitur tekstur, bentuk, dan warna menggunakan Artificial Neural Network dan Decision Tree J48

\begin{tabular}{|c|c|c|c|c|c|c|c|c|c|}
\hline \multirow{2}{*}{ Fitur } & \multirow{2}{*}{$\begin{array}{l}\text { split } \\
\text { ratio }\end{array}$} & \multicolumn{4}{|c|}{ Artificial Neural Network } & \multicolumn{4}{|c|}{ Decision Tree J48 } \\
\hline & & $\mathrm{P}$ & $\mathrm{R}$ & $\mathrm{F}$ & $\mathrm{A}$ & $\mathrm{P}$ & $\mathrm{R}$ & $\mathrm{F}$ & A \\
\hline \multirow{6}{*}{$\begin{array}{c}\text { Tekstur + } \\
\text { Bentuk + } \\
\text { Warna }\end{array}$} & $10: 90$ & 0.746 & 0.730 & 0.725 & $73.04 \%$ & 0.818 & 0.770 & 0.777 & $76.95 \%$ \\
\hline & $30: 70$ & 0.933 & 0.926 & 0.923 & $92.59 \%$ & 0.995 & 0.995 & 0.995 & $99.47 \%$ \\
\hline & $40: 60$ & 0.871 & 0.870 & 0.869 & $87.03 \%$ & 0.986 & 0.985 & 0.985 & $98.45 \%$ \\
\hline & $70: 30$ & 0.961 & 0.957 & 0.955 & $95.67 \%$ & 0.984 & 0.981 & 0.981 & $98.14 \%$ \\
\hline & $80: 20$ & 0.934 & 0.917 & 0.912 & $91.66 \%$ & 1.000 & 1.000 & 1.000 & $100 \%$ \\
\hline & $90: 10$ & 0.966 & 0.963 & 0.963 & $96.29 \%$ & 1.000 & 1.000 & 1.000 & $100 \%$ \\
\hline
\end{tabular}

memiliki perbedaan pada cara proses klasifikasinya. Kemudian pada Decision Tree J48 memiliki nilai Untuk itu Decision Tree J48 lebih memiliki nilai minimal pada split ratio 10:90 dengan nilai precision keakuratan dengan menonjolkan proses klasifikasi 0.820 , recall $0.749, f$-measure 0.730 dan nilai accuracy berdasarkan dari fitur yang dilakukan. Serta dalam 74.89\%. Serta pada Tabel 5 juga mempunyai nilai Artificial Neural Network mengandalkan keseluruhan terbaik baik Artificial Neural Network maupun Decision objek untuk mencari citra dari burung lovebird.

Pada Tabel 5 merupakan hasil perbandingan pada tingkat 2 fitur tekstur dan warna. Dalam hal ini perbandingan antara Artificial Neural Network dan Decision Tree $\mathrm{J48}$ berdasarkan gabungan dari fitur tekstur dan warna. Diawali dengan nilai minimal yang ada pada Artificial Neural Network memiliki nilai pada Tree J48. Untuk Artificial Neural Network nilai terbaik ada pada split ratio 90:10 dengan nilai precision 0.924, recall 0.907, f-measure 0.904 dan nilai accuracy 90.74\%. Kemudian pada Decision Tree J48 memiliki nilai terbaik yang ada pada split ratio 80:20 dan 90:10 dengan nilai precision 1.000 , recall 1.000 , f-measure 1.000 dan nilai accuracy $100 \%$.

split ratio 10:90 dengan nilai precision 0.657 , recall Pada Tabel 5 ini tingkat keakuratan dalam proses 0.632, f-measure 0.620 dan nilai accuracy 61.16\%. klasifikasi citra burung lovebird lebih optimal

DOI: https://doi.org/10.29207/resti.v5i4.3210

Creative Commons Attribution 4.0 International License (CC BY 4.0) 
menggunakan Decision Tree J48. Metode Decision Tree Dalam fitur tingkat tiga tersebut Decision Tree J48 $J 48$ memiliki hasil accuracy mencapai $100 \%$, sedangkan memiliki nilai proses klasifikasi yang lebih baik dalam Artificial Neural Network hanya memiliki hasil dibandingkan dengan Artificial Neural Network. Serta maksimal $87.40 \%$. Hal ini membuktikan bahwa dalam hal ini pada proses klasifikasi burung lovebird Decision Tree J48 pada tingkat kedua tingkat tekstur dan bisa menggunakan split ratio 80:20 dan 90:10 dengan warna memiliki nilai keakuratan sangatlah baik nilai keakuratan yang sempurna. Berdasarkan dibandingkan dengan Artificial Neural Network.

Kemudian pada Tabel 6 ini merupakan hasil perbandingan tingkat kedua antara fitur warna dengan fitur bentuk. Dalam hal ini diawali dengan nilai terendah dari masing-masing bagian yaitu dimulai dari Artificial Neural Network dengan nilai minimal berada pada split ratio 10:90 yang memiliki nilai precision 0.765 , recall 0.728 , f-measure 0.726 dan nilai accuracy $72.83 \%$. Serta dalam Decision Tree J48 memiliki nilai minimal yang ada pada split ratio 10:90 dengan nilai precision 0.845 , recall 0.805 , f-measure 0.787 dan nilai accuracy $80.45 \%$. dalam hal ini nilai minimal pada kedua bagian memiliki kesamaan pada split ratio 10:90. Kemudian pada Tabel 6 juga memiliki nilai maksimal pada Artificial Neural Network yang ada di split ratio 50:50 dengan nilai precision 0.905 , recall $0.874, f$-measure 0.5869 dan nilai accuracy $87.40 \%$. Serta pada Decision Tree J48 memiliki nilai maksimal yang berada pada split ratio 30:70, 50:50, 70:30, 80:20, dan 90:10 dengan nilai yang akurat pada nilai precision 1.000 , recall $1.000, f$ measure 1.000 dan nilai accuracy $100 \%$.

Dengan ini bisa diketahui bahwa dalam pengujian yang terdapat pada split ratio 10:90 masih sangat minimal untuk proses klasifikasi burung lovebird. Serta dalam hal ini nilai yang akurat ada pada Decision Tree J48 yang memiliki nilai akurasi mencapai $100 \%$. Pada Tabel 6 dalam 1 fitur warna dan bentuk bisa menggunakan Decision Tree $\mathrm{J} 48$ pada split ratio yang sudah mencapai tingkat keakuratan yang sempurna.

Pada Tabel 7 ini merupakan perbandingan antara ketiga Hasil membuktikan dengan pengujian ekstraksi tingkat fitur, baik dari fitur tekstur, fitur bentuk dan fitur warna. pertama dapat memperbaiki kinerja dan menghasilkan Proses penggabungan dari ketiga fitur tersebut berguna accuracy yang terbaik. Berdasarkan hasil dan untuk mempercepat proses klasifikasi burung lovebird. pembahasan dari pengujian yang dilakukan pada Kemudian pada Tabel 7 diawali dengan nilai minimal penelitian ini dapat disimpulkan bahwa algoritma yang ada pada Artificial Neural Network yang berada Decision Tree J48 lebih baik dari Artificial Neural pada split ratio 10:90 dengan nilai precision 0.746 , Network dari semua tingkat fitur yang diuji. Serta dalam recall 0.730, f-measure 0.725 dan nilai accuracy Decision Tree $\mathrm{J} 48$ memiliki nilai yang tinggi 73.04\%. Serta pada Decision Tree J48 juga memiliki dibandingkan dengan Artificial Neural Network dalam nilai minimal yang berada pada split ratio 10:90 dengan proses klasifikasi citra burung lovebird. Kekurangan dari nilai precision 0.818 , recall 0.770 , f-measure 0.777 dan penelitian ini pada proses klasifikasi citra jenis burung nilai accuracy $76.69 \%$. Kemudian pada Tabel 7 juga lovebird dengan algoritma Decision Tree J48 masih memiliki nilai maksimal dalam penggabungan tiga fitur menggunakan sistem segmentasi manual dalam tersebut. Diawali dengan Artificial Neural Network yang menghilangkan background pada burung lovebird. ada pada split ratio 90:10 dengan nilai precision 0.966, Untuk penelitian selanjutnya dapat mengembangkan recall 0.963 , f-measure 0.963 dan nilai accuracy sistem segmentasi secara otomatis yang mampu 96.29\%. Selanjutnya untuk Decision tree J48 memiliki menghilangkan background menggunakan machine nilai maksimal pada split ratio 80:20 dan 90:10 dengan learning.

nilai precision 1.000 , recall 1.000, f-measure 1.000 dan

nilai accuracy $100 \%$. 


\section{Daftar Rujukan}

[1] M. H. Triambudi, T. K. Sanjaya, and A. Nurlifa, "Sistem Pakar Diagnosa Penyakit Pada Burung Lovebird Menggunakan Metode Certainty Factor," Informatika, vol. 3, no. 1, pp. 1-11, 2018, doi: 10.37438/jimpv1i2121.

[2] A. Z. Masyhuda, N. Santoso, and E. Santoso, "Pengembangan Sistem Informasi Manajemen Ternak Burung Lovebird berbasis Android," J. Pengemb. Teknol. Inf. dan Ilmu Komput., vol. 3, no. 7, pp. 6896-6903, 2019, doi: 10.89064/2678.v8i3.896.

[3] Y. E. Era, R. Anggie, and T. A. Darma, "Membongkar Sangkar Emas Pasar Bebas Melalui Strategi Gacoan," Accountong Prof. Journal(Apaji), vol. 2, no. 1, pp. 1-9, 2020, doi: https://doi.org/10.35593/apaji.v2i1.6.

[4] K. Rinartha, M. Rusli, and L. G. S. Kartika, "Pemasaran Online Burung Kicau Pada Peternak di Desa Baler Bale Agung," Widyabhakti J. Ilm. Pop., vol. I, no. 1, pp. 81-85, 2018, doi: https://doi.org/10.23359/widyabhakti.v1i1.2.

[5] M. Misdiyanto, Y. S. Tjahjaningsih, and I. Aprilia, "Identifikasi Jenis-Jenis Burung Lovebird Menggunakan Pengolahan Citra Digital dengan Metode K-Means Clustering," J. Sains Komput. Inform., vol. 4, no. September, pp. 445-456, 2020, doi: [14 http://dx.doi.org/10.30645/j-sakti.v4i2.236.

[6] S. N. Shaputri, B. Hidayat, and U. Sunarya, "Klasifikasi Lovebird Berdasarkan Bentuk Kepala Dan Warna Dengan Metode Local Binary Pattern (LBP) Dan Fuzzy Logic Lovebird Classification Based On Head Shape And Colors Using Local Binary Pattern (LBP) Method And Fuzzy Logic," vol. 2, no. 2, pp. 79-85, 2015, doi: https://doi.org/10.14587/1036v2i2.2.

[7] M. E. Al Rivan and S. Devella, "Pengenalan Iris Menggunakan Fitur Local Binary Pattern Dan RBF Classifier,” Simetris J. Tek. Mesin, Elektro dan Ilmu Komput., vol. 11, no. 1, pp. 97-106, 2020, doi: 10.24176/simet.v11i1.3717.

[8] A. S. Indrawanti and E. P. Mandyartha, "Deteksi Limfoblas Pada Citra Sel Darah Menggunakan Fitur Geometri Dan Local Binary Pattern," J. Nas. Tek. Elektro dan Teknol. Inf., vol. 7, no. 4, pp. 404-410, 2018, doi: 10.22146/jnteti.v7i4.458.
[9] H. Junaedi, M. Hariadi, and I. K. E. Purnama, "Profiling Gaya Sutradara Berdasarkan Penempatan Posisi Kamera Dengan Fuzzy Logic,” J. Edukasi dan Penelit. Inform., vol. 4, no. 2, p. 147, 2018, doi: 10.26418/jp.v4i2.28993.

[10] R. Satriatama, D. Darlis, and P. Pangaribuan, "Sistem Kontrol Troli Rotari Sebagai Tempat Penitipan Barang Otomatis Menggunakan Fuzzy Logic," ELKOMIKA J. Tek. Energi Elektr. Tek. Telekomun. Tek. Elektron., vol. 8, no. 3, p. 575, 2020, doi: 10.26760/elkomika.v8i3.575.

[11] A. Y. Rahman and I. Istiadi, "LoveBird Type Classification Using Fuzzy Logic and Artificial Neural Networks With Three Levels Of Features," 2020.

[12] M. Sipan and R. K. Pramuyanti, "Deteksi Kualitas Kuning Telur Ayam Kampung Menggunakan Ekstraksi Ciri Secara Statistika Orde Satu Berbasis Logika Fuzzy," Elektrika, vol. 12, no. 2, p. 73, 2020, doi: 10.26623/elektrika.v12i2.2783.

13] Z. Z. R. Permana, S. T. Rasmana, and I. Puspasari, "Prediksi Jarak Bola Pada Citra Kamera Katadioptrik Menggunakan Metode Artifical Neural Network," ELKOMIKA J. Tek. Energi Elektr. Tek. Telekomun. Tek. Elektron., vol. 9, no. 2, p. 279, 2021, doi: 10.26760/elkomika.v9i2.279.

[14] A. T. Sari and E. Haryatmi, "Penerapan Convolutional Neural Network Deep Learning Dalam Pendeteksian Citra Biji Jagung Kering," J. Resti (Rekayasa Sist. dan Teknol. Informasi), vol. 1, no. $10, \quad$ pp. 265-271, 2021, doi: https://doi.org/10.29207/resti.v5i2.3040.

[15] Y. W. Pamungkas, A. Adiwijaya, and D. Q. Utama, "Klasifikasi Gambar Gigitan Ular Menggunakan Regionprops dan Algoritma Decision Tree," J. Sist. Komput. dan Inform., vol. 1, no. 2, p. 69, 2020, doi: 10.30865/json.v1i2.1789.

16] K. Adi, S. Pujiyanto, O. D. Nurhayati, and A. Pamungkas, "Beef Quality Identification Using Thresholding Method And Decision Tree Classification Based On Android Smartphone," J. Food Qual., vol. 2017, 2017, doi: 10.1155/2017/1674718.

[17] A. Fouad, H. M. Moftah, and H. A. Hefny, "Brain Diagnoses Detection Using Whale Optimization Algorithm Based On Ensemble Learning Classifier," Int. J. Intell. Eng. Syst., vol. 13, no. 2, pp. 40-51, 2020, doi: 10.22266/ijies2020.0430.05.

DOI: https://doi.org/10.29207/resti.v5i4.3210 